\title{
Ko au ko te taiao, ko te taiao ko au - I am the environment and the environment is me: A Māori theology of the environment
}

Note: This article was first presented as a keynote address at the Sea of Faith Conference 2018, 2-4 November 2018, Silverstream, Aotearoa New Zealand.

Ko au ko te taiao, ko te taiao ko au - I am the environment and the environment is me. This article will present a Māori theology of the environment based on whakapapa (genealogy), whenua (land), wairua (spirit), whānau (family), and whakapono (faith).

\section{Whakapapa}

Hikurangi te maunga

Rangitāiki te awa

Koura te tangata

Te Patuheuheu te hapū

Ngāi Tūhoe te iwi

Tāwhiuau te maunga

Rangitāiki te awa

Tangiharuru te tangata

Ngāti Manawa te iwi
Hikurangi is the mountain

Rangitāiki is the river

Koura is the ancestor

Te Patuheuheu is the clan

Ngāi Tūhoe is the tribe

Tāwhiuau is the mountain

Rangitāiki is the river

Tangiharuru is the ancestor

Ngāti Manawa is the tribe 
Tūwatawata te maunga

Whirinaki te awa

Wharepākau te tangata

Hikurangi te maunga

Waiapū te awa

Porourangi te tangata

Ngāti Porou te iwi
Tūwatawata is the mountain

Whirinaki is the river

Wharepākau is the ancestor

Hikurangi is the mountain

Waiapu is the river

Porourangi is the ancestor

Ngāti Porou is the tribe

My identity and whakapapa inform my theology of the environment. My pepeha triangulates my multiple connections to land, mountains, rivers, ancestors, hapū (sub-tribes) and iwi (tribes). Whakapapa is a matrix for understanding and relating to the world. Whakapapa literally means to layer up. It describes and illustrates the connections between Māori and the environment from the creation to the present.

The Māori creation story begins with Te Kore or Te Korekore. The term Te Kore is often compared with the biblical notion of the void, the nothingness. However, the Reverend Māori Marsden declares:

Te Korekore is the realm between non-being and being: that is, the realm of potential being. This is the realm of primal, elemental energy or latent being. It is here that the seed-stuff of the universe and all created things gestate. It is the womb from which all things proceed (Royal, 2003, p.20).

Emanating from the cosmic incubator of Te Kore emerged Te Pō (the darkness); and out of the numerous developmental stages of Te Pō came the primordial parents, Papatūānuku (Earth Mother) and Ranginui (Sky Father) who, while incessantly clasped to one another, produced progeny (Marsden in Royal, 2003; Mikaere, 2011; Reilly, 2004). The offspring of these ancient parents grew dissatisfied with the darkness that resulted from their parent's unending embrace, and so one of the children, Tānenuiarangi, pushed Ranginui and 
Papatūānuku apart, which moved the universe into a new stage, Te Ao Mārama (the World of Light) (Mikaere, 2011; Reilly, 2004).

Within Te Ao Mārama, human life was created through the materialisation of human form, and through sexual intercourse. Tānenuiarangi formed the first woman, Hineahuone, from the red clay at Kurawaka - the pubic area of Papatūānuku - and procreated with her. From this union came human-kind. Tānenuiarangi's previous sexual relationships had been with non-human partners; and from these encounters came the flora and fauna of the world. From a Māori perspective, therefore, the plants and creatures of the world are our senior relatives and as such we have obligations to them.

\section{Whenua}

The whenua informs my environmental theology. Whenua is the Māori word for both land and afterbirth. For Māori, Williams (2004) states, whenua is more than 'land'; “...it is much more than a mere resource; it is a large part of Māori mana as well as being the primary ancestor; it embodies the past and, at the same time, is the foundation for future generations" (p. 50). Marsden argues:

Whenua was the term both for the natural earth and placenta. This is a constant reminder that we are of the earth and therefore earthly. We are born out of the placenta and therefore human. As a human mother nourished her child in the womb and then upon her breast after the child's birth, so does Mother Earth (Royal, 2003, p. 68).

In most iwi the whenua, or placenta in this context, is buried in a place of significance; and at death, the remains are interred in the whenua - the land. Williams (2004) opines that "[t]his symbolises interconnectedness between people and the land..." (p. 50) through genealogy and the cycle of life and death. Māori ancestors are therefore spiritually and physically anchored to the land. Higgins (2012) states: "Land is one of the key elements to Māori identity. It embodies the histories, 
genealogies, and spiritual connections to the past, present, and future" (p. 412).

Whenua is a word that is intimately linked to Papatūānuku wife of Ranginui, the primordial ancestors of ongoing influence from which Māori and all living things descend (Marsden in Royal, 2003; Moorfield, 2011; Williams, 2004). Marsden states: "Papatuanuku - 'Land from beyond the veil; or originating from the realm beyond the world of sense-perception', was the personified form of whenua - the natural earth" (Royal, 2003, p. 44). As posterity of Papatūānuku, Māori are connected to the whenua through whakapapa. Whakapapa connections to whenua are essential to Māori identity (Cheater \& Hopa, 1997; Higgins, 2012; Walker, 1990; Williams, 2004). Marsden contends:

Papatuanuku is our mother and deserves our love and respect. She is a living organism with her own biological systems and functions creating and supplying a web of support systems for all her children whether man, animal, bird, tree, grass, microbes or insects (Royal, 2003, p. 45).

Stressing the importance of Māori identity with whenua, Williams (2004) argues: "Māori are not just joined to the land, they are an integral part of nature, with a relationship to every other living thing, defined by whakapapa" (p. 50). Mikaere (2011) maintains that from the perspective of a Māori worldview, the entire universe is connected:

...the single most important message to emerge from our creation stories is that we are connected, by whakapapa, to one another and to all other parts of creation. Everything in the natural world, ourselves included, shares a common ancestry (p. 313).

Referring to Māori as children of Papatūānuku and the connections of all living things, Marsden maintains: 
Papatuanuku's children live and function in a symbiotic relationship. From unicellular through to more complex multicellular organisms each species depends upon other species as well as its own, to provide the basic biological needs for existence. The different species contribute to the welfare of other species and together they help to sustain the biological functions of their primaeval mother, herself a living organism (Royal, 2003, p. 45).

\section{Wairua}

Wairua informs my environmental theology. Wairua can be described as 'spirit', while the word wairua itself means 'two waters' (Pere, 1991). Dr Rose Pere (1991) explains that wairua possesses both positive and negative elements, affirming, as an example, that water can both provide and enhance life or take it away; here, balance is key. According to Professor Sir Mason Durie (1994), taha wairua is about faith in and communion with unseen and unspoken energies. This correlates with Pere's (1991) argument that "[t]he physical realm is immersed and integrated with the spiritual realm. A powerful belief in spirituality governs and influences the way one interacts with other people, and relates to her or his environment" (p. 16). Taha wairua or spirituality is commonly thought to be the most critical aspect of Māori wellbeing because, if the wairua is not taken care of, a person is disposed to illness and misfortune (Durie, 1994). Durie (1994) maintains:

A spiritual dimension encompasses religious beliefs and practices but is not synonymous with regular churchgoing or strong adherence to a particular denomination. Belief in God is one reflection of wairua, but it is also evident in relationships with the environment (p. 70).

\section{Whānau and whakapono}

Whānau means family but it is also a word that means to give birth. Whānau can be conceptualised in the form of the 
harakeke plant. At the centre are the children, and surrounding the children are parents and grandparents. I come from a whānau of extremely spiritual people. We are a whānau of deep whakapono or faith. From a young age, I have always been obsessed with religion. I was born into a whakapapa of syncretistic theology: a mixture of traditional Māori beliefs and rituals blended seamlessly with various Christian denominations and Ringatū - a syncretistic religion created by the nineteenth-century Māori prophet Te Kooti Arikirangi Te Turuki. My great-grandfather, Hāpurona Maki Nātana, who was married to Pare Koekoeā Rikiriki, was of Patuheuheu and Ngāti Manawa descent. His mother was Rangimaea Fitzgerald who was born of a Ngāti Manawa mother, and an Irish father. She was a devout Catholic. My grandmother, Rēpora Marion Brown (nee Maki), who contributed significantly to the development of my theology, told me that her grandmother Rangimaewa was a 'staunch Catholic' who fasted often, refrained from eating meat on Fridays, and frequently prayed the Rosary.

In the late 1980s when I was perhaps 8 or 9 years old, I became very interested in Catholicism. I attended Sacred Heart Catholic church in Murupara. Going to church was a case of doing as the 'Romans' do. I crossed myself with holy water upon entering the church and genuflected with both sincerity, and great drama, my eyes fixated on the seemingly life-sized, 3D, blood-drenched crucifix. One irreverent comment I had heard was that when the red light is on, Jesus is home (in the tabernacle); but when it is off, he is out shopping! A member of the Christian brothers had wanted me to become an altar boy. I would have thoroughly enjoyed wearing a cassock and surplice, ringing sanctus bells, and swinging a thurible, but it was not meant to be as I was not Catholic, and had not been baptised at all.

Nanny Pare was Ringatū, and so was her daughter, my grandmother. Koro Hāpurona and Nanny Pare had many, many children. They were baptised alternatively: the first Ringatū, the second Catholic, and so on. Their last child was baptised Presbyterian. Throughout my growing-up years, I attended many Ringatū services with my grandmother and other 
members of my whānau. Some of these services took place at the marae and many others took place at the farmhouse of my grandmother's sister; her husband was considered somewhat of an authority on spiritual affairs. When my uncle was spiritually unwell, we took him to see Nan's brother-in-law who provided solutions to help with his healing.

In the early 1990s, I attended the Elim church in Murupara. Some of the people at church were very strict. Some of the other kids were not allowed to watch cartoons, as talking turtles and characters with superpowers were considered to be ungodly. During my time with Elim, I attended a Christian camp. At this camp we prayed in tongues for the fall of Saddam Hussein. We raised our hands and voices in prayer and praise to the Lord. I had no idea how to pray in tongues, but I was told that it is a unique language that only God can understand. To me, it sounded like gibberish. I decided that my particular style of glossolalia would be to repeat "peanut butter" over and over again; that seemed to do the trick!

In 1996, when I was 16, I converted to Mormonism. I had been seduced by a sense of absolute belonging coupled with fun activities and the potential of one day serving a mission and emulating the actions of the American missionaries that taught me about Mormonism. In 1997 I attended the Church College of New Zealand for my final year of high school. In 2002 I was assigned by the Church to serve a two-year mission. I had doors slammed in my face. I was accused of worshipping the devil. I was asked to show my "magical Mormon underwear". I was verbally abused, threatened with violence, and chased by vicious dogs. I was severely overfed by well-meaning and hyperhospitable Pasifika families. I was embraced by "mission aunties" who baked fresh bread, and cooked boil-up. I rode bicycles and walked the streets, come rain, hail or storm, door knocking and preaching the Mormon gospel: the good news that an American prophet named Joseph Smith had restored the true gospel to the earth! In 2003 I was removed from the mission and excommunicated from the Church by the Mission leadership for a severe breach of Church rules, thus ending a six-year term with the Mormons. 
My maternal grandfather was Ngāti Porou from Te Araroa. $\mathrm{He}$, like most of the iwi, was raised Anglican. He was not a church-going man, but he did believe in God. Some years following my excommunication from the Mormon Church, I decided to follow the religion of my grandfather's Ngāti Porou people, Mihingare or Anglican. Archbishop Don Tamihere of Ngāti Porou maintains: "...religion - which I'm more inclined to refer to as whakapono - is an integral part of Ngāti Porou life. It's been blended into our tikanga to such an extent that it's really hard to tell where Christianity begins and tikanga Māori ends" (Husband, 2018, n.p.).

My maternal grandmother, known affectionately to me as simply 'Nan', was born in 1940 . She was 40 years old when I was born in 1980. I spent 37 years listening to Nan's stories. Stories about her upbringing, her life growing up in Waiōhau, a tiny village settlement in the Eastern Bay of Plenty, living next to the marae. Her faith in God - as a practising Ringatu - was immovable. She prayed for God's guidance and protection in her life and in the lives of all of her family members, especially her mokopuna (grandchildren). The following description of God represents my environmental theological explorations, influenced by Nan.

God is the pulse of the universe

God is collecting rongoā in the bush to heal the whānau

God is the taniwha lurking in the river

God is the potato we touch when exiting the urupa

God is the branch the tohunga uses to sprinkle us with water

God is the tokotoko pointing to Papatūānuku and Ranginui

God is ngā Atua Māori in the environment around us

God is the log floating up-stream

(adapted from Rangiwai, 2018, pp. 171-172)

\section{God is the pulse of the universe}

God is Te Atua. The word atua refers to an ancestor with continuing influence; or a god, demon, supernatural being, deity, ghost, strange being, or an object of superstitious regard 
(Moorfield, 2011). While the word atua is commonly translated as 'god', Professor John Moorfield (2011) argues that this is a misconception of the original meaning. Father Hēnare Tate (2012) maintains that the missionaries took the word atua and used it to describe the Christian God.

\section{God is collecting rongoa in the bush to heal the whānau}

My whānau are a whānau of healers. Collecting rongoā (medicine) from the forest and using it in the process of healing is part of our practice as a whānau. Karakia or incantations to Tānenuirangi, the Atua of the forest, are uttered to ensure safe passage. We have an intimate knowledge of the ngahere (forest) and the flora and fauna therein. Rongoā is part of our whānau theology and is therefore part of my theology of the environment.

\section{God is the taniwha lurking in the river}

Taniwha are experienced by Māori in many ways and in many forms. Moorfield (2011) defines taniwha as water spirit, monster, dangerous water creature, powerful creature, chief, powerful leader, something or someone awesome. Taniwha may appear in many forms such as logs, reptiles, whales, and are believed to live in the sea, lakes, and rivers (Moorfield, 2011). Taniwha are regarded by some as guardians but may also cause harm to humans (Moorfield, 2011). Nan taught me that some taniwha or "manas" as she called them, had the potential to protect us, or to "slap us". A balance had to be achieved. Tikanga had to be observed. Karakia had to be used. Safe passage had to be negotiated.

\section{God is the potato we touch when exiting the urupa}

Nan told me that in more recent times some of the tapu (ritual restriction) of the urupā (burial grounds) at Waiōhau had been lifted to make things easier for the next generation. Presently the urupā is open, with the various denominations mixed together. When Nan was growing up the denominations were 
fenced-off from each other: the Ringatū in one area; the Catholics in another area; and the Protestants in yet another area. The tapu of the Ringatu part of the cemetery was believed to be so great that if a non-Ringatū entered, they would die. Nan said that when exiting the cemetery, the people had to touch a potato, held by a Ringatū priest to remove the tapu of the urupā. After touching the potato, the people had to go with the tohunga (priestly expert) down to the river to whakawātea, to engage in a cleansing ritual.

\section{God is the branch the tohunga uses to sprinkle us with water}

At the river the Ringatū tohunga used a branch - which he dipped into the river - to sprinkle water over the people while at the same time articulating Ringatu karakia. This ritual was a means of engaging in whakawātea to free the people from tapu. The use of water and the use of karakia as a way of negating tapu is a critical part of my environmental theology.

\section{God is the tokotoko pointing to Papatūānuku and Ranginui}

When a koroua stands to speak with his tokotoko (speaking stick), he points to the various geographical locations of the whenua. He points to the earth, to Papatūānuku; and he points skyward to Ranginui. The tokotoko can be used as a pneumonic device as a means to recall whakapapa, history, and to acknowledge our ancestors.

\section{God is ngā Atua Māori in the environment around us}

Atua Māori exist in the environment around us. Ngā Atua commonly referred to, somewhat inaccurately, as the gods reside and are active in the physical world. Atua (singular) or ngā Atua (plural) are more accurately described as ancestor deities with continuing influence over particular domains, such as, Tangaroa, Atua of the sea, and Tāne, Atua of the forest. Iwi, 
hapū, and whānau also had specific Atua, kaitiaki (guardians) and other spiritual beings such as taniwha who provided protection or, conversely, punished people for breaching appropriate behavioural protocols; these entities could be turned against one's enemies (Simmons, 1986). In my whānau we are acutely aware of our kaitiaki who appear in the forms of certain animals; we acknowledge them and we recognise that we are to engage in appropriate behaviour within their realms in the environment.

\section{God is the log floating up-stream}

Logs have been mysteriously known to float up-stream. Some say that this is a sign of some sort. Others, that the log is the manifestation of something spiritual, perhaps, of a taniwha or kaitiaki. Commenting on tipua, Tregear (1904) states that when they appear they are "...not always visible in a frightful or terrifying shape but assumed the appearance of ordinary creatures or things" (Tregear, 1904, p. 538), and that “...at Rangitaiki River was a tipua log of totara wood above which no eel would pass" (Tregear, 1904, p. 539). Cowan (1930) also writes about a number of "taniwha-logs" or "demon-logs" that moved through lakes and rivers; these were considered to be omens warning of impending war or death.

\section{Conclusion}

I grew up hearing stories that, to some, might be considered terrifying. Stories about carvings that would come to life and cause tragedies. Stories about cannibalism. Stories about Te Kooti's guns in the Horomanga ranges. Stories about special trees with life-giving properties. Stories about the trees used to hang tūpāpaku (corpses). The phenomena and tohu (signs) of the Māori world are, to me, physical signs from the spiritual world. When interpreted, they can be used as a means of guiding our lives. 
This article discussed a Māori theology of the environment based on whakapapa (genealogy), whenua (land), wairua (spirit), whānau (family), and whakapono (faith):

Whakapapa signifies our descent from the Gods, from Sky Father and Earth Mother, and from their son Tāne who formed the first human being from red clay and mated with her, producing human kind. Tāne's previous sexual encounters were with non-human beings which produced the other species of the planet. All other species, therefore, are seen to be our relatives. Sustainability therefore, is measured by the strength of our relationships with our relatives, the plants and animals that surround us, and more importantly with our ancient parents, Papatūānuku and Ranginui -for without earth and sky, we cease to exist.

Whenua describes land and placenta. We descend from the first human being who was fashioned from red clay. Whenua is a critical part of Māori identity. Without whenua, our identity as Māori suffers. Whenua is our mother, Papatūānuku. From the perspective of sustainability, we are meant to maintain a positive relationship with the whenua upon which we live and we are to treat her as we would treat our own mothers.

Wairua is spirit. Te Ao Wairua, the spiritual world manifests itself in the physical world. Signs and symbols present themselves through the environment, and we decipher their meanings. For some, a Fantail flying indoors is a sign of impending death, for others a red eel symbolises death or tragedy. For my family, a green gecko guides us when we are lost. For others, the mokomoko, or lizard, represents misfortune. Spiritual signs from the environment form part of our moral compass. Concerning, sustainability these signs are indicators of the health of our relationship with the spiritual realm.

Whānau can be conceptualised in the form of the harakeke plant. The link between the whānau and harakeke demonstrates the importance of the environment to whānau. It is through whānau that knowledge of the world around us is passed on. It is through whānau that whakapapa is embodied, remembered, and aknowledged. It is through the unit of 
whānau that we first engage with our environment, and recognise the critical balance that must be maintained with regard to environmental sustainability.

Whakapono is the our belief and faith in the spirtual world. This belief and faith is based in the environment around us as the spiritual world manifests itself in the physical. Our whakapono is one that relies on the environment to exist. Our Atua are located in the environment and we need them to provide for us. We must respect their realm and work toward a balance between our needs and the needs of our environment. In this sense, our whakapono is a religion of sustainability. It is a religion of reciprocity, harmony, incantations, rituals, faith, healing and so much more. Ko au ko te taiao, ko te taiao ko au - I am the environment and the environment is me. 


\section{Bibliography}

Binney, J. (1995). Redemption songs: A life of Te Kooti Arikirangi Te Turuki. Auckland, New Zealand: University Press and Bridget Williams.

Cheater, A. \& Hopa, N. (1997). Representing identity. In A. James, J. Hockey \& A. Dawson (Eds.), After writing culture: Epistemology and praxis in contemporary anthropology (pp. 208-23). Oxon, United Kingdom: Routledge.

Cowan, J. (1930). The Maori: Yesterday and to-day. Christchurch, New Zealand: Whitcombe \& Tombs.

Cox, J. L. (2014). The invention of God in indigenous societies. Durham, United Kingdom: Acumen Publishing.

Durie, M. (1994). Whaiora: Māori health development. Melbourne, Australia: Oxford University Press.

Higgins, R. (2012). New Zealand: The Māori people. In M. D. Palmer \& S. M. Burgess (Eds.), The Wiley-Blackwell companion to religion and social justice (pp. 412-424). Chichester, United Kingdom: Blackwell Publishing.

Husband, D. (2018, April 8). Don Tamihere: Brought up on 'the old world'. Retrieved from: https://e-tangata.co.nz/news/dontamihere-brought-up-on-the-back-of-the-old-world

Mikaere, A. (2011). Colonising myths - Mãori realities: He rukuruku whakaaro. Wellington, New Zealand: Huia Publishers \& Te Tākupu, Te Wānanga o Raukawa.

Moorfield, J. C. (2011). Te Aka-Māori-English, English-Māori dictionary. Auckland, New Zealand: Pearson.

Pere, R. T. (1991). Te Wheke: A celebration of infinite wisdom. Gisborne, New Zealand: Ao Ako Global Learning New Zealand Limited.

Rangiwai, B. (2018). "God is..." : A personal theology based on stories from my grandmother. Te Kaharoa: The eJournal on Indigenous Pacific Issues, 11(1), 171-172. Retrieved from: https://www.tekaharoa.com/index.php/tekaharoa/article/view/ 1 $79 / 159$

Reilly, M. P. J. (2004). Te tīmatanga mai o ngā atua. In T. M. Ka‘ai, J. C. Moorfield, M. P. J. Reilly, \& S. Mosley (Eds.), Ki te whaiao: An introduction to Māori culture and society (pp.1-12). Auckland, New Zealand: Pearson.

Royal, T. C. (Ed.) (2003). The woven universe: Selected writings of Rev. Māori Marsden. Ōtaki, New Zealand: Estate of Rev. Māori Marsden.

Schrempp, G. (1993). Magical arrows: The Maori, the Greeks, and the folklore of the universe. Madison, WI: The University of Wisconsin Press.

Shirres, M. (1997). Te tangata: The human person. Auckland, New Zealand: Accent.

Simmons, D. R. (1986). Iconography of New Zealand Maori religion. Leiden, The Netherlands: E. J. Brill. 
Tate, H. (2012). He puna iti i te ao mārama: A little spring in the world of light. Auckland, New Zealand: Libro.

Te Ao Hou (1955, December). Children write from Waiohau. Retrieved from:

http://teaohou.natlib.govt.nz/journals/teaohou/issue/Mao13TeA /c25.html

Tregear, E. (1904). The Maori race. Whanganui, New Zealand: Dudingston Willis.

Walker, R. (1990). Ka whawhai tonu matou: Struggle without end. Auckland, New Zealand: Penguin.

Williams, J. (2004). Papa-tūā-nuku: Attitudes to land. In T. M. Ka'ai, J. C. Moorfield, M. P. J. Reilly \& S. Mosley (Eds), Ki te whaiao: An introduction to Māori culture and society (pp. 50-60). Auckland, New Zealand: Pearson. 